\title{
THE STRUCTURE AND MECHANICAL PROPERTIES OF Ni-Mo PM STEELS WITH ADDITION OF Mn AND Cu
}

\author{
E. Lichańska, P. Kulecki, K. Pańcikiewicz
}

\begin{abstract}
The aim of the study was to evaluate the effect of chemical composition on the structure and mechanical properties of $\mathrm{Mn}-\mathrm{Ni}$-Mo and $\mathrm{Ni}-\mathrm{Mo}-\mathrm{Cu} \mathrm{PM}$ steels. Pre-alloyed powder Astaloy 85Mo, diffusion alloyed powders Distaloy $A Q$ and Distaloy $A B$ produced by Höganäs, low carbon ferromanganese, carbonyl nickel powder T255 with three-dimensional filamentary structure and graphite CU-F have been used as the basic powders. Three mixtures with compositions of $\mathrm{Fe}-1 \% \mathrm{Mn}-(0.5 / 1.75) \% \mathrm{Ni}$ (0.5/0.85)\%Mo-0.8\% $\mathrm{C}$ and $\mathrm{Fe}-1.75 \% \mathrm{Ni}-0.5 \% \mathrm{Mo}-1.5 \% \mathrm{Cu}-0.8 \% \mathrm{C}$ were prepared in a Turbula mixer. Green compacts were single pressed in a steel die at $660 \mathrm{MPa}$ according to PN-EN ISO 2740 standard. Sinterhardening was carried out at $1250^{\circ} \mathrm{C}$ in a mixture of $95 \% \mathrm{~N}_{2}+5 \% \mathrm{H}_{2}$ for 60 minutes. Mechanical tests (tensile, bend, hardness) and microstructural investigations were performed. Additionally, XRD and EDS analysis, fractographic investigations were carried out. The microstructures of steels investigated were mainly bainitic or bainitic-martensitic. Addition 1\% Mn to Distaloy AQ based steel caused increase of tensile properties (YS from 422 to $489 \mathrm{MPa}$, UTS from 522 to $638 \mathrm{MPa}$, TRS from 901 to $1096 \mathrm{MPa}$ ) and decrease of plasticity (elongation from 3.65 to $2.84 \%$ ).
\end{abstract}

Keywords: sinterhardening, diffusion alloyed powders, fractography, ferromanganese, EDS analysis

\section{INTRODUCTION}

Molybdenum as an alloying addition in steels increases hardenability, tensile strength and hardness [1-3]. Sintered Mo steels based on mixtures of elemental powders can possess high heterogeneity. As molybdenum is characterized by low diffusion rates in iron, even at high temperatures molybdenum-containing phases can be carbides [3-5]. One of the effective ways of molybdenum addition into PM steels is mixing this element in the pre-alloyed powder state [2].

Heat treatment of nickel-containing sintered steels causes an increasing of mechanical properties. During sintering at temperatures lower than the melting temperature of nickel $\left(1453^{\circ} \mathrm{C}\right) \mathrm{Ni}$-rich areas occur [6-7]. Diffusion bonds between iron and nickel particles in the solid state directly increase plasticity in PM steels [8].

The main motivation of production of PM Mn steels was the low price of Mn and beneficial influence on mechanical properties. However, high affinity to oxygen results in manganese being introduced into the powder mixture as a ferroalloy [1]. Many publications suggest that an addition of $0.5 \%-3 \% \mathrm{Mn}$ caused increasing hardenability, tensile strength, transverse rupture strength and hardness in PM steels $[\underline{1,3,9,10]}$. Sintering of PM Mn steels in atmospheres containing $\mathrm{N}_{2}$ and $\mathrm{H}_{2}$ significantly limits $\mathrm{Mn}$ oxidation [11]. 
Copper as an alloying element in PM steel causes improvement of hardenability and in an amount of at least 3\% may increase shrinkage [6]. During production of PM steels in industrial conditions (sintering temperature $1120^{\circ} \mathrm{C}$ ) copper is in a liquid phase and it accelerates and makes more uniform alloying of sintered Mn steels [12]. Consequently, it can increase mechanical properties [6]

\section{MATERIALS}

The following base powders were used:

- pre-alloyed iron-powder (produced by Höganäs):

- Astaloy 85Mo consisting of $0.85 \% \mathrm{Mo}, 99.15 \% \mathrm{Fe}$,

- diffusion alloyed iron powders (produced by Höganäs):

- Distaloy AQ consisting of $0.5 \% \mathrm{Ni}, 0.5 \% \mathrm{Mo}, 99.0 \% \mathrm{Fe}$,

- Distaloy AB consisting of $1.75 \% \mathrm{Ni}, 0.5 \% \mathrm{Mo}, 1.5 \% \mathrm{Cu}, 99.0 \% \mathrm{Fe}$,

- low-carbon ferromanganese (77 \% Mn, $1.3 \% \mathrm{C})$ produced by Eramet Comilog Manganese, particle size lower than $40 \mu \mathrm{m}$,

- carbonyl nickel powder T255 with three-dimensional filamentary structure produced by Vale, particle size $2.2 \div 2.8 \mu \mathrm{m}$,

- graphite powder C-UF (produced by Höganäs),

- From base powders, using a Turbula mixer for 30 minutes, three powder mixtures with composition (Table 1):

- $\mathrm{Fe}-1 \% \mathrm{Mn}-0.5 \% \mathrm{Ni}-0.5 \% \mathrm{Mo}-0.8 \% \mathrm{C}$ (mark as $1 \mathrm{AQ}$ ),

- $\mathrm{Fe}-1 \% \mathrm{Mn}-1.75 \% \mathrm{Ni}-0.85 \% \mathrm{Mo}-0.8 \% \mathrm{C}$ (mark as $1 \mathrm{MoN})$,

- $\mathrm{Fe}-1.75 \% \mathrm{Ni}-0.5 \% \mathrm{Mo}-1.5 \% \mathrm{Cu}-0.8 \% \mathrm{C}$ (mark as $\mathrm{AB}$ ) were prepared.

After pressing in a steel die at $660 \mathrm{MPa}$, the green compacts according to 2740 ISO standard were sintered at $1250^{\circ} \mathrm{C}$ for $60 \mathrm{~min}$ in $5 / 95$ hydrogen-nitrogen mixture, in a semi-closed container. Heating and cooling rates were $75^{\circ} \mathrm{C} / \mathrm{min}$. and $65^{\circ} \mathrm{C} / \mathrm{min}$., respectively.

Tab.1. Established chemical composition of investigated PM steels (\% mas.).

\begin{tabular}{|c|c|c|c|c|c|}
\hline Designation & $\mathrm{Mn}$ & $\mathrm{Mo}$ & $\mathrm{Ni}$ & $\mathrm{Cu}$ & $\mathrm{C}$ \\
\hline $1 \mathrm{AQ}$ & 1 & 0.5 & 0.5 & - & \multirow{2}{*}{0.8} \\
\cline { 1 - 3 } $\mathrm{AB}$ & - & 0.5 & \multirow{2}{*}{1.75} & 1.5 & \multirow{2}{*}{0.8} \\
\cline { 1 - 3 } & 1 & 0.85 & & - & \\
\hline
\end{tabular}

\section{INVESTIGATIONS}

Sintered steels were mechanically tested. Yield strength $\left(\mathrm{YS}_{0.2}\right)$, ultimate tensile strength (UTS), bend strength (TRS), and hardness (HV 0.1) were recorded. The tensile test was carried out according to PN EN 10002-1 standard at a cross-head speed of $1 \mathrm{~mm} / \mathrm{min}$. Bend tests were carried out according to a PN-EN 3325 standard parallel to the pressing direction. The investigation of apparent and cross-sectional hardness was carried out using the Vickers method according to the PN-EN ISO 3870 standard, parallel to the pressing direction.

To complement mechanical tests, metallographic and fractography investigations were carried out using optical microscopy (LOM) and Scanning Electron Microscopy (SEM), respectively. Additionally, X-ray investigations were performed using diffractometer D500 Kristalloflex Siemens with a monochromatic radiation lamp with copper anode $\mathrm{Cu}\left(\lambda_{\mathrm{K} \alpha}=1.54 \mathrm{~A}\right)$. EDS analysis of chemical compositions was performed on scanning electron microscopes, including Merlin Gemini II (ZEISS). 


\section{RESULTS}

\section{Microstructure}

The structure of PM steels investigated was mainly bainitic or martensitic-bainitic with low amounts of retained austenite. This is the effect of sinterhardening cooling rate $65^{\circ} \mathrm{C} / \mathrm{min}$.

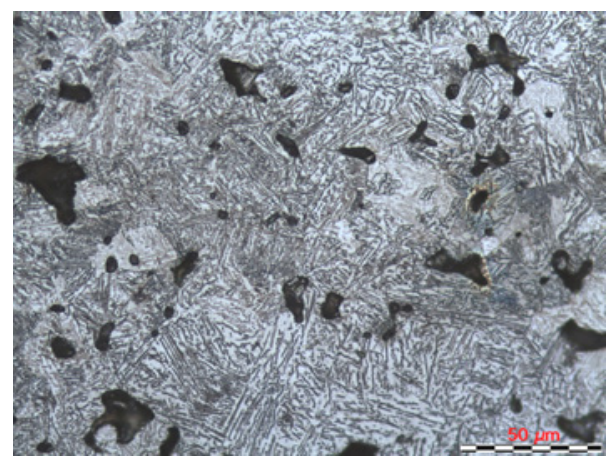

Fig.1. Microstructure of investigated steel 1AQ (marker $50 \mu \mathrm{m}$ ).

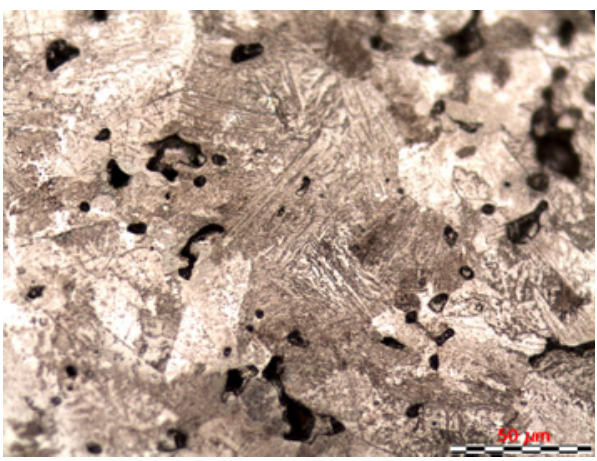

Fig.2. Microstructure of investigated steel $\mathrm{AB}$ (marker $50 \mu \mathrm{m})$.

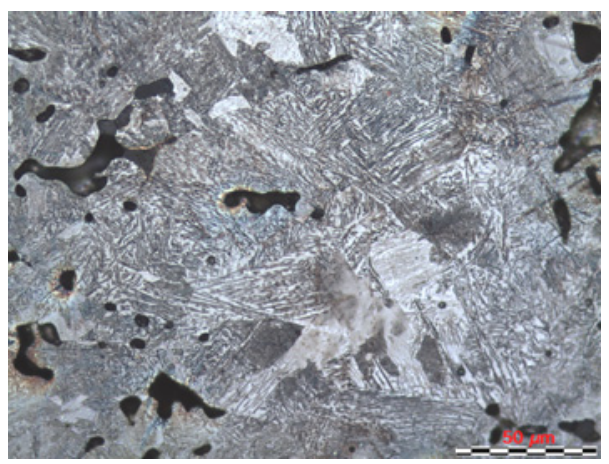

Fig.3. Microstructure of investigated steel $1 \mathrm{MoN}$ (marker $50 \mu \mathrm{m}$ ).

\section{Mechanical properties}

Table 2 shows physical and mechanical properties of investigated steels.

Tab.2. As sintered densities (measured by the geometric method) and mechanical properties of investigated PM steels (30 samples per variant - mean values and standard deviations).

\begin{tabular}{|c|c|c|c|c|c|c|}
\hline Steel & Density $\left[\mathrm{gcm}^{-3}\right]$ & UTS [MPa] & $\mathrm{YS}_{0.2}[\mathrm{MPa}]$ & $\mathrm{E}[\%]$ & $\mathrm{TRS}[\mathrm{MPa}]$ & $\mathrm{HV} 0.1$ \\
\hline \multirow{2}{*}{$1 \mathrm{AQ}$} & \multirow{2}{*}{6.84} & 638 & 489 & 2.84 & 1096 & 248 \\
& & \pm 33 & \pm 43 & \pm 0.46 & \pm 107 & \pm 32 \\
\hline \multirow{2}{*}{$\mathrm{AB}$} & \multirow{2}{*}{6.88} & 683 & 510 & 2.96 & 1151 & 252 \\
& & \pm 36 & \pm 70 & \pm 0.46 & \pm 112 & \pm 57 \\
\hline \multirow{2}{*}{$1 \mathrm{MoN}$} & \multirow{2}{*}{6.87} & 768 & 677 & 1.36 & 1220 & 352 \\
& & \pm 48 & \pm 67 & \pm 0.25 & \pm 184 & \pm 129 \\
\hline
\end{tabular}




\section{Fractography}

In Figures 4 - 6 the results of fractographic observations are presented. For 1AQ steel the fracture (Fig. 4) is ductile with fine shallow dimples along interfaces - surfaces of bainitic packets, coarse dimples initiated by pores and additionally some failure in the austenite initiated by small pores [13]. The fracture surface of AB PM steel, Figure 5, consisted of ductile and cleavage areas. Some areas were characterized by cleavage of bainite/pearlite and by river patterns. The $1 \mathrm{MoN}$ steel fracture surface is mainly brittle, Fig. 6 , (note the river patterns) with cleavage of bainite areas and some ductile failure in austenite [13].

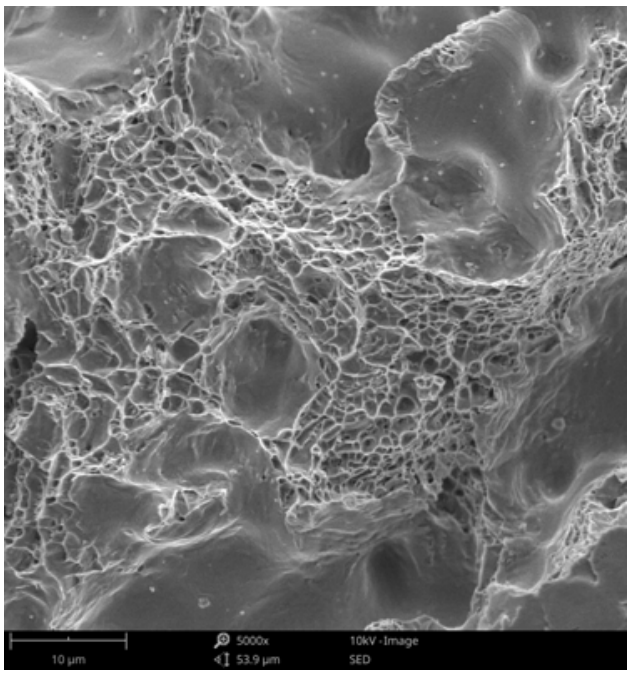

Fig.4. The fracture surface of PM steel 1AQ (marker $10 \mu \mathrm{m})$.

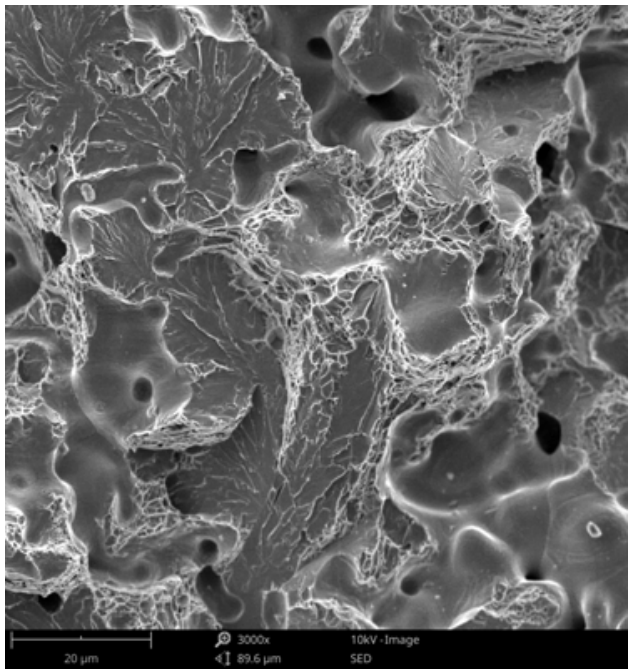

Fig.5. The fracture surface of PM steel AB (marker $20 \mu \mathrm{m})$.

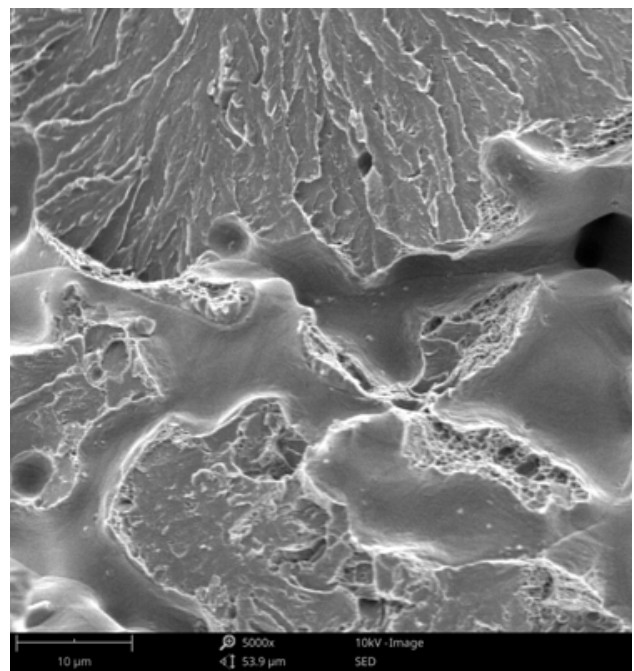

Fig.6. The fracture surface of PM steel $1 \mathrm{MoN}$ (marker $10 \mu \mathrm{m})$. 


\section{XRD investigations}

Based on ICDD data, diffractograms (Figs. 7-9) were analysed. The diffractogram for $1 \mathrm{AQ}$ steel (Fig. 7) presented 3 phases: $\mathrm{Fe} \alpha$ and a trace amount of $\mathrm{Fe} \gamma$ and $\mathrm{Fe}_{3} \mathrm{C}$. Steel $\mathrm{AB}$ was characterized by $\mathrm{Fe} \alpha$ and $\mathrm{Fe}_{3} \mathrm{C}$ phases. XRD analysis revealed $\mathrm{Fe} \alpha, \mathrm{Fe} \gamma$ and a trace amount of $\mathrm{Fe}_{3} \mathrm{C}$ in $1 \mathrm{MoN}$ steel.

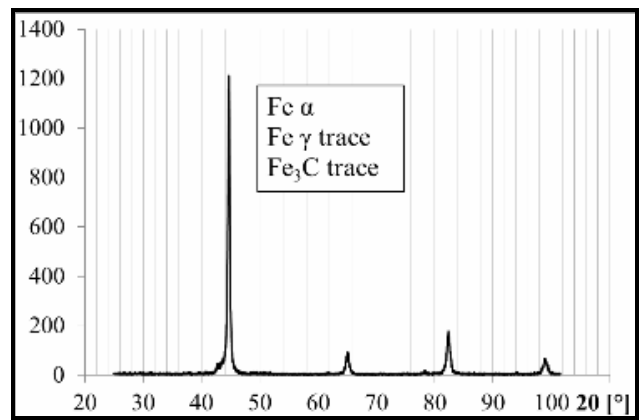

Fig.7. Record of diffraction angle for $1 \mathrm{AQ}$ PM steel

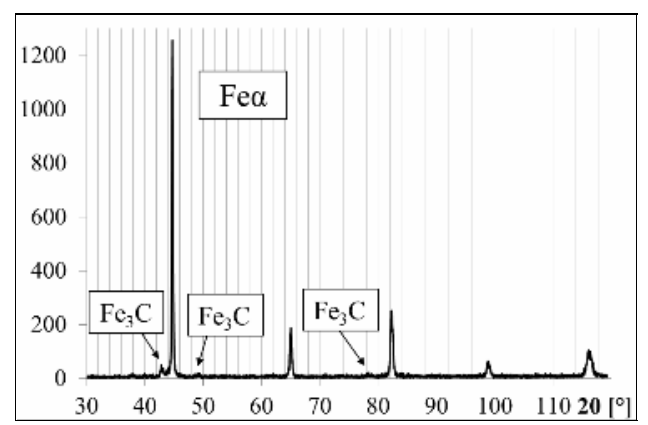

Fig.8. Record of diffraction angle for PM steel $\mathrm{AB}$

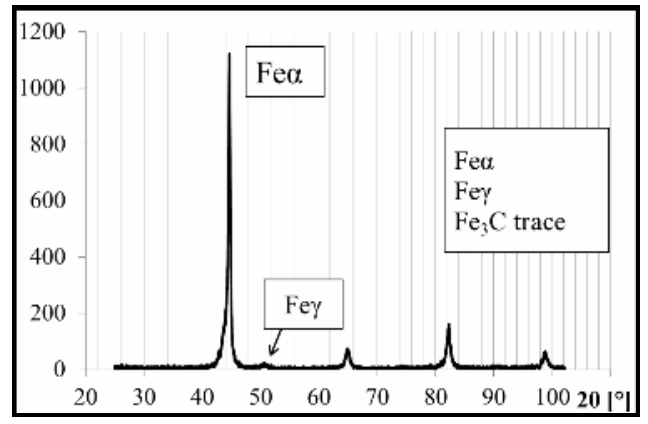

Fig.9. Record of diffraction angle for PM steel $1 \mathrm{MoN}$

\section{EDS analysis}

EDS analyses of chemical compositions for investigated steels were performed using scanning electron microscopy (regions 800x800 $\mu \mathrm{m}$ ). EDS maps (Figures 10-21) were prepared on scanning electron microscope Merlin Gemini II (ZEISS). The retained austenite is rich in nickel [8,10]. Chemical composition of 1AQ steel (Table 3) shows local differences in $\mathrm{Ni}$ and $\mathrm{Mo}$ concentrations in comparison with established chemical compositions (Table 1). For AB and 1MoN steels, EDS investigations (Table 3) confirmed the established amount of alloying elements $\mathrm{Mn}$ and Ni (Table 1) and a slightly higher amount of Mo. 
Tab.3. EDS analysis of chemical composition of investigated PM steels in \%.

\begin{tabular}{|c|c|c|c|c|c|c|}
\hline \multirow{2}{*}{$\begin{array}{c}\text { Element } \\
\text { Symbol }\end{array}$} & \multicolumn{2}{|c|}{$1 \mathrm{AQ}$} & \multicolumn{2}{c|}{ AB } & \multicolumn{2}{c|}{$1 \mathrm{MoN}$} \\
\cline { 2 - 7 } & $\begin{array}{c}\text { Atomic } \\
\text { Conc. }\end{array}$ & $\begin{array}{c}\text { Weight } \\
\text { Conc. }\end{array}$ & $\begin{array}{c}\text { Atomic } \\
\text { Conc. }\end{array}$ & $\begin{array}{c}\text { Weight } \\
\text { Conc. }\end{array}$ & $\begin{array}{c}\text { Atomic } \\
\text { Conc. }\end{array}$ & $\begin{array}{c}\text { Weight } \\
\text { Conc. }\end{array}$ \\
\hline $\mathrm{Fe}$ & 96.50 & 96.45 & 95.74 & 95.69 & 94.97 & 94.81 \\
\hline $\mathrm{Mo}$ & 0.82 & 1.40 & 0.70 & 1.20 & 1.03 & 1.78 \\
\hline $\mathrm{Mn}$ & 1.29 & 1.27 & - & - & 1.04 & 1.02 \\
\hline $\mathrm{Ni}$ & 0.33 & 0.34 & 1.48 & 1.56 & 1.65 & 1.73 \\
\hline $\mathrm{Cu}$ & - & - & 0.80 & 0.91 & - & - \\
\hline $\mathrm{Si}$ & 1.07 & 0.54 & 1.28 & 0.64 & 1.18 & 0.59 \\
\hline $\mathrm{S}$ & & & & & 0.12 & 0.07 \\
\hline
\end{tabular}

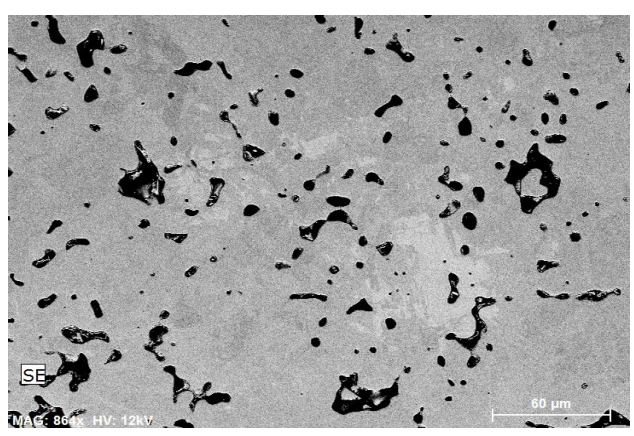

Fig.10. EDS analyzed area 1AQ steel (marker $60 \mu \mathrm{m})$.

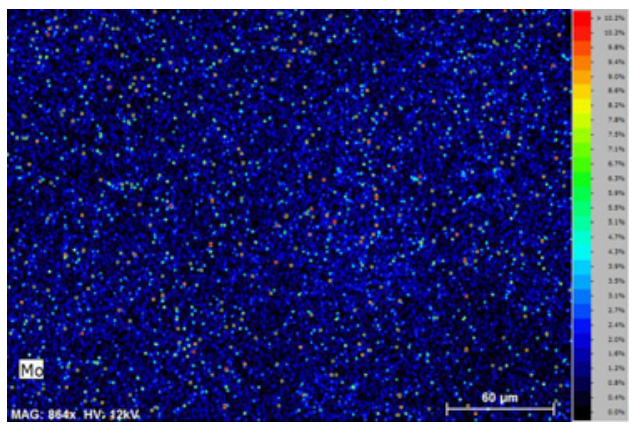

Fig.12. Mo EDS element mapping in steel 1AQ (marker $60 \mu \mathrm{m}$ ).

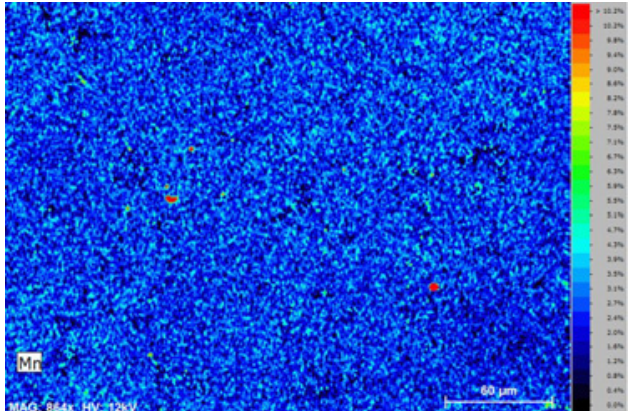

Fig.11. Mn EDS element mapping in steel 1AQ (marker $60 \mu \mathrm{m})$.

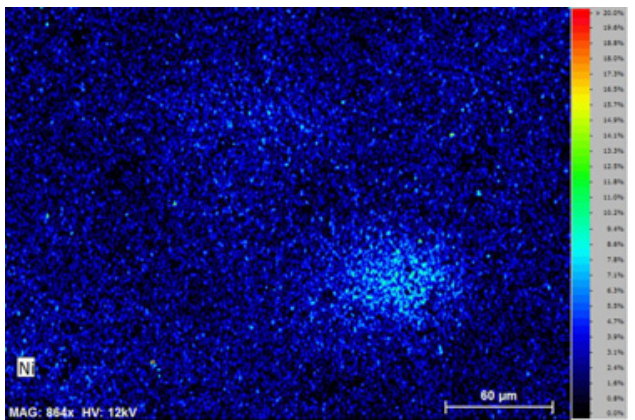

Fig.13. Ni EDS element mapping in steel 1AQ (marker $60 \mu \mathrm{m}$ ). 


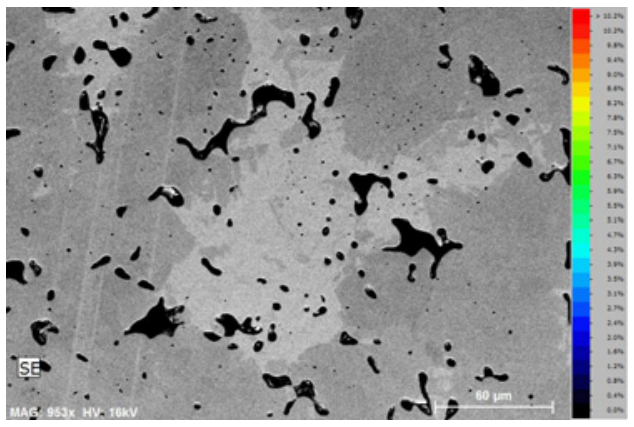

Fig.14. EDS analyzed area AB steel (marker $60 \mu \mathrm{m})$.

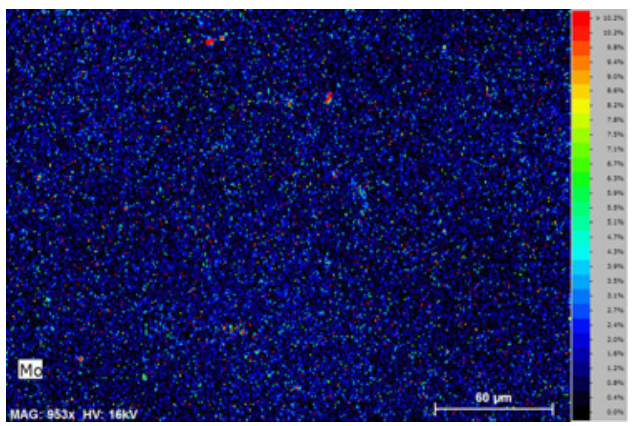

Fig.16. Mo EDS element mapping in steel AB (marker $60 \mu \mathrm{m}$ ).

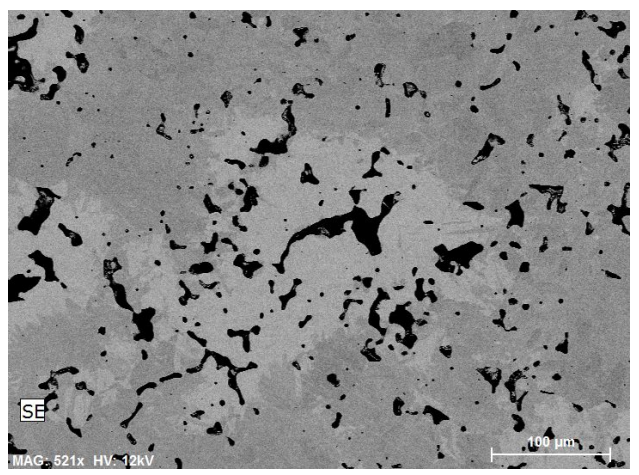

Fig.18. EDS analyzed area $1 \mathrm{MoN}$ steel (marker $100 \mu \mathrm{m}$ ).

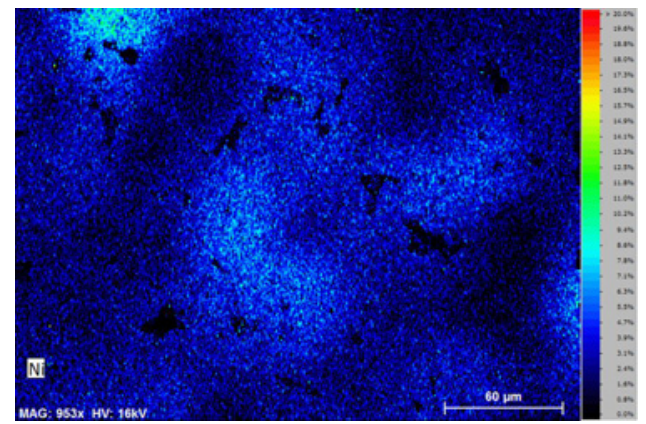

Fig.15. Ni EDS element mapping in steel AB (marker $60 \mu \mathrm{m}$ ).

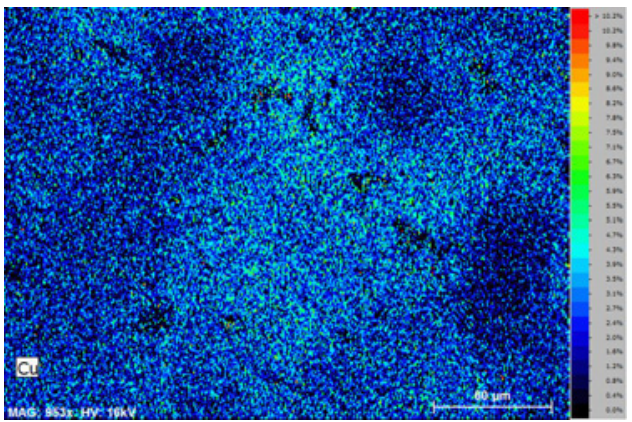

Fig.17. Cu EDS element mapping in steel AB (marker $60 \mu \mathrm{m}$ ).

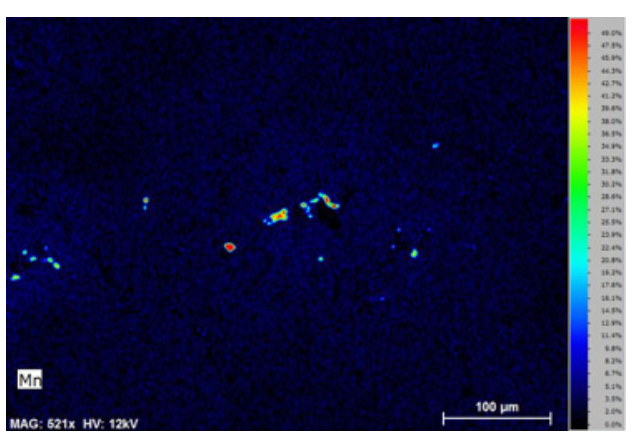

Fig.19. Mn EDS element mapping in steel $1 \mathrm{MoN}$ (marker $100 \mu \mathrm{m}$ ). 


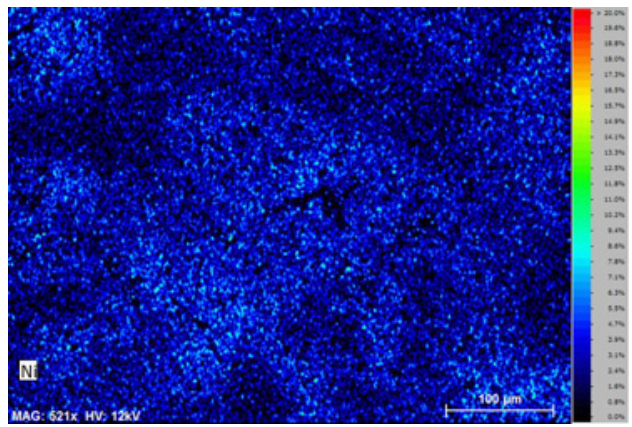

Fig.20. Ni EDS element mapping in steel $1 \mathrm{MoN}($ marker $100 \mu \mathrm{m}$ ).

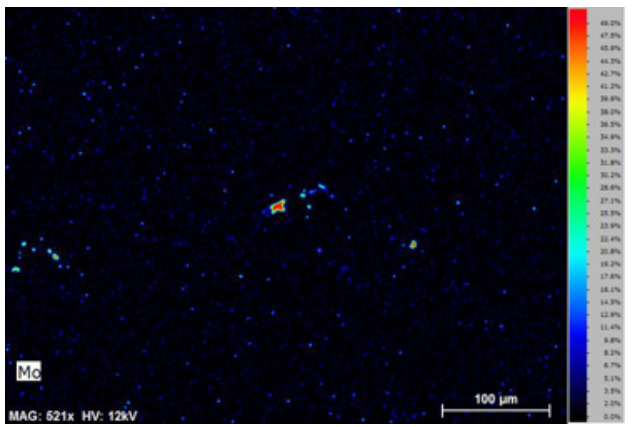

Fig.21. Mo EDS element mapping in steel $1 \mathrm{MoN}$ (marker $100 \mu \mathrm{m})$.

\section{DISCUSSION}

Following the data presented in [14], steel based on Distaloy AQ powder with an addition of $0.8 \% \mathrm{C}$ is characterized by the following mechanical properties: (UTS - 522 $\mathrm{MPa}, \mathrm{YS}_{0.2}-422 \mathrm{MPa}$, TRS - $901 \mathrm{MPa}, \mathrm{HV} 0.1$ - 221, E - 3.65 \%). As was shown in Table 2, for steel based on Distaloy AQ powder, the addition of $1 \% \mathrm{Mn}$ caused an increase in tensile properties (UTS - $638 \mathrm{MPa}, \mathrm{YS}_{0.2}$ - $489 \mathrm{MPa}$, TRS- 1096 - MPa, HV0.1 - 248) and decreasing plasticity (elongation 2.84\%) [12]. The strengthening of steel with the addition of $\mathrm{Mn}$ is connected with increasing hardenability $[9,12,13]$. The metallographic and XRD studies (Figs. 7-9) showed that steel $1 \mathrm{AQ}$ was characterized by bainitic microstructure [16]. EDS maps (Figs. 10 and 13) have shown that Ni in this steel segregated during sintering and caused the presence of retained austenite. In material with low retained austenite content, when grain size is small, fatigue cracks are blocked [16,17].

Following the MPIF 35 standard, steel produced from diffusion alloyed iron powder Distaloy AB, is characterized by (with density $6.75-7.25 \mathrm{~g} / \mathrm{cm}^{3}$ ) UTS: $480-710$ $\mathrm{MPa}$, YS : 400-500 MPa and elongation 1\% [19]. Ultimate tensile and yield strength of steel $\mathrm{AB}$ described in this paper were in this range, and elongation $(\sim 3 \%)$ higher than in the MPIF Standard (1\%), which may be connected with segregation of nickel [19]. EDS maps revealed that bright areas (Figs. 14 and 15) were rich in nickel.

PM steels produced from iron powder, e.g. NC 100.24 or ASC 100.29 and lowcarbon ferromanganese, were characterized by low geometric density $\left(6.62-6.70 \mathrm{~g} / \mathrm{cm}^{3}\right)$ $[16,17]$. Using diffusion alloyed powder (e.g. Distaloy AQ) or pre-alloyed powder (Astaloy $8 \overline{5 \mathrm{Mo})}$ as a base powder, with the same amount of low-carbon ferromanganese, caused increasing density $\left(6.84-6.87 \mathrm{~g} / \mathrm{cm}^{3}\right)$. It is connected with more plasticity and irregular shape of Astaloy 85Mo and Distaloy AQ particles in comparison to pure iron powders.

Steel $1 \mathrm{MoN}(\mathrm{Fe}-2 \% \mathrm{Mn}-0.85 \% \mathrm{Mo}-1.75 \% \mathrm{Ni}-0.8 \% \mathrm{C})$ was characterized by the highest tensile properties (UTS - $768 \mathrm{MPa}$, YS - $677 \mathrm{MPa}, \mathrm{HV} 0.1$ - 352, TRS - $1220 \mathrm{MPa}$ ) and the lowest plasticity (elongation $1.36 \%$ ). Metallographic and XRD investigations (Figs. 1-3 and 7-9) showed that in the microstructure of $1 \mathrm{MoN}$ steel bainite occurs and a high amount of martensite. The high amount of alloying elements caused high hardenability of $1 \mathrm{MoN}$ steel $[3,4,8]$. The used rate of cooling $65^{\circ} \mathrm{C} / \mathrm{min}$. was too high to cause this steel to be sinterhardened $[16,17$ and an additional heat treatment, e.g. tempering [24], is required. Fractography investigations (Figs. 4-6) confirmed the brittle character of researched $1 \mathrm{MoN}$ steel [25]. Element mapping in steel $1 \mathrm{MoN}$ (Fig. 20) showed that $\mathrm{Ni}$ is 
evenly distributed in matrix which is connected with the very fine particle size of $\mathrm{Ni}$ powder $(2.2 \div 2.8 \mu \mathrm{m})$ and with good homogenizing of the mixture. EDS investigations (Table 3) revealed some amount of $\mathrm{S}$ in $1 \mathrm{MoN}$ steel. It is the effect of impurities which got into the powder mixture during processing. Impurities like $\mathrm{Si}$ and $\mathrm{S}$ also could decrease plasticity of the investigated steel.

\section{CONCLUSION}

The studies lead to the following conclusions:

1. Addition $1 \% \mathrm{Mn}$ to steel produced from Distaloy AQ caused increase of tensile properties.

2. Independently of the way nickel was introduced into the powder mixtures, some amount of Ni segregated during sintering and it was revealed as an area which has not etched.

3. Steel $1 \mathrm{MoN}$ requires additional heat treatment.

4. 1AQ steel (D. AQ $+1 \% \mathrm{Mn}$ ) can be described as a sinterhardened steel and, because of its properties, can be a good alternative for $\mathrm{AB}$ steel.

\section{Acknowledgements}

The financial support of the Ministry of Science and Higher Education under AGH contract no 11.11.110.299 is gratefully acknowledged.

Appreciation is also expressed to Prof. A. S. Wroński for his advice and comments on the manuscript, as well as its editing.

\section{REFERENCES}

[1] Lichańska, E., Sułowski, M., Ciaś, A.: Arch. Metall. Mater., vol. 61, 2016, no. 1, p. 109

[2] Lindsley, B., Rutz, H.: Adv. Powder Metall. Part. Mater., 2008, p. 9

[3] Danninger, H., Pöttschacher, R., Bradac, S., Šalak, A., Seyrkammer, J.: Powder Metall., vol. 48, 2005, no. 1, p. 23

[4] Danninger, H.: Powder Metall. Int., vol. 24, 1992, p. 73

[5] Danninger, H.: Powder Metall. Int., vol. 24, 1992, p. 163

[6] Missol, W.: Spiekane części maszyn, 1972

[7] Ciaś, A.: Development and Properties of Fe-Mn-(Mo)-(Cr)-C Sintered Structural Steels, 2004

[8] Fiał, C., Dudrova, E., Kabatova, M., Kupkova, M., Selecka, M., Sułowski, M., Ciaś, A.: Arch. Metall. Mater., vol. 60, 2015, p 783

[9] Ciaś, A., Czarski, A.: Arch. Metall. Mater., vol. 58, 2013, no. 4, p. 1045

[10] Zhang, Z., Frisk, K., Salwén, A., Sandström, R.: Powder Metall., vol. 47, 2004, no. 3, p. 239

[11] Lindsley, B., James, WB. In: Euro PM 2010 Florence, no. 5, 2010, p. 1

[12] Salak, A., Selecká, M.: Manganese in powder metallurgy steels, 2012

[13] Dudrova, E., Kabátová, M. In: Workshop - Fractography of Sintered Materials Principles and Application, 2015

[14] Lichańska, E., Kulecki, P., Tenerowicz, M.: Naučni Izv. na Naučno-tehničeskiâ S’uz po Mašinostroene, in print, 2017

[15] Kulecki, P., Lichańska, E.: Sci. Proc., vol. 1, 2016, no. 187, p. 253

[16] Schade, C., Murphy, T., Lawley, A., Doherty, R.: Microstructure and mechanical properties of a bainitic PM Steel. Hoeganas Corporation, 2015

[17] Krauss, G.: ASM Int. 1990, p. 497

[18] Dobrzański, LA.: Podstawy nauki o materiałach i metaloznawstwo, 2002 
[19] MPIF Standard 352016 Edition, 2016, p. 1

[20] Sinka, V., Selecká, M., Salak, A.: Mater. Sci. Forum, vol. 416-418, 2003, no. 1, p. 455

[21] Kulecki, P., Tenerowicz, M., Lichańska, E.: Naučni Izv. na Naučno-tehničeskiâ S'uz po Mašinostroene, in print, 2017

[22] James, WB. In: PM2 TEC '98, 1998, p. 1

[23] Material and Powder Properties. Höganäs Handb. Sintered Components, 2013

[24] Babakhani, A., Haerian, A., Ghambri, M.: J. Mater. Process. Technol., vol. 204, 2008, no. $1-3$, p. 192

[25] Hull, D.: Fractography: Observing, Measuring and Interpreting Fracture Surface Topography, 1999 